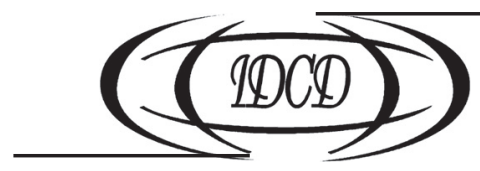

УДК 314.335.044

\title{
Т.Ю. ІВАЩЕНКО
}

старш. наук. співроб. Центру комплексних

досліджень з питань антимонопольної політики

E-mail: fort_una@meta.ua

\section{ОЦІНКА СУЧАСНИХ ЗАХОДІВ ПІДТРИМКИ СІМЕЙ 3 ДІТЬМИ В УКРАЇНI}

У статті дано оцінку впливу сучасних заходів соціально-демографічної політики України у сфері підтримки сімей з дітьми на дітородну активність населення, визначено причини низької мотивації до дітонароджень серед молодих українських сімей та обгрунтовано перспективні напрями забезпечення базових можливостей для реалізації дітородного потенціалу нації. 3 використанням статистичних методів дослідження здійснено порівняння обсягу необхідних прямих та альтернативних витрат на виховання і розвиток дитини та фактичних можливостей середньостатистичної української сім'ї. За результатами досліджень зроблено висновки щодо доцільності часткових інвестицій держави у виховання і розвиток дітей віком від 3 до 18 років. Підкреслено важливість запровадження компенсаційних виплат замість звичайної грошової допомоги з метою підвищення захисту державних виплат від нецільового використання.

Ключові слова: державна соціальна допомога, прожитковий мінімум, мотивація до дітонародження, альтернативні витрати, компенсаційні виплати.

\section{Т.Ю. Иващенко}

старш. науч. сотрудн. Центра комплексных

исследований по вопросам антимонопольной политики

E-mail: fort_una@meta.ua

\section{ОЦЕНКА СОВРЕМЕННЫХ МЕР ПОДДЕРЖКИ СЕМЕЙ С ДЕТЬМИ В УКРАИНЕ}

В статье дана оценка влияния современных програм социально-демографической политики Украины в сфере поддержки семей с детьми на детородную активность населения, определены причины низкой мотивации к деторождению среди молодежи и рассмотрены вероятные варианты обеспечения базовых возможностей для реализации детородного потенциала нации. С использованием статистических методов исследования произведено сравнение необходимых прямых и альтернативных издержек на воспитание и развитие ребенка и фактических возможностей среднестатистической украинской семьи. По результатам исследований сделаны выводы о целесообразности частичных инвестиций государства в воспитание и развитие детей в возрасте от 3 до 18 лет. Подчеркнута важность введения компенсационных выплат вместо обычной денежной помощи с целью повышения защиты государственных выплат от нецелевого использования.

Ключевые слова: государственная социальная помощь, прожиточный минимум, мотивация к деторождению, альтернативные издержки, компенсационные выплаты. 


\section{T. Ivaschenko}

Senior Researcher, Centre of Complex Researches in Competition Policy

03035, Kyiv, Metropolitan Vasil Lypkivsky Street, 45

\section{EVALUATION OF CURRENT MEASURES TO SUPPORT FAMILIES WITH CHILDREN IN UKRAINE}

The article assesses the effects of the modern socio-demographic policy of Ukraine in support of families with children on the childbearing activity of the population, identifies the reasons for the low motivation to having child in young Ukrainian families, substantiates possible directions of providing basic capabilities for realization of childbearing potential of the nation. Using statistical research methods comparisons were made of the amount of necessary direct and opportunity costs for the upbringing and development of a child and the actual capabilities of the average Ukrainian family. According to the research results conclusions were made regarding the advisability of partial realization of state investment in the education and development of children aged 3 to 18 years.

Key words: state social protection, living wage, childbearing motivation, opportunity costs, compensation payments.

Постановка проблеми. В останні роки питання соціальної підтримки сімей з дітьми стало однією з найактуальніших проблем соціально-демографічного розвитку України. Високий рівень безробіття серед молоді, низький рівень мінімальних гарантій оплати праці, що не відповідає реальній вартості життя, відсутність ефективних програм забезпечення житлом молодих сімей, низька якість та недостатній рівень доступності послуг з догляду за дітьми дошкільного та молодшого шкільного віку - усі ці негаразди, негативно впливаючи на якість життя потенційних батьків, тривалий час ставали причиною відмови від народження бажаної кількості дітей. I, хоча в Україні є значна кількість прав та соціальних гарантій матерям у перші роки життя малюка, маємо констатувати актуальність впровадження додаткових заходів соціальної підтримки сімей з дітьми для покращення показників відтворення населення.

Аналіз останніх досліджень і публікацій. Дослідженням проблем та перспектив соціально-демографічної політики України в сфері підтримки сімей з дітьми присвятили свої праці багато вітчизняних науковців: Черниш О.I. (Chernysh O.I.), Чижова Л.С. (Chyzhova L.S.), Гоноров С.B. (Honorov Ye.V.), Задоєнко Л.В. (Zadoienko L.V.), Терещенко Г.I. (Tereschenko H.I.), Ничипоренко С.В. (Nychyporenko S.V.), Черенько Л.М. (Cheren'ko L.M.), Полякова C.B. (Poliakova S.V.), Заяць B.C. (Zaiac' V.S.), Демчук M.В. (Demchuk M.V.), Лібанова E.M. (Libanova E.M.), Стешенко B.C. (Steshenko V.S.), Пирожков C.I. (Pyrozhkov S.I.) та інші. При цьому провідні експерти неодноразово ставили під сумнів ефективність здійснюваних заходів соціально-демографічної політики України у сфері підтримки сімей з дітьми.

Формулювання цілей статті. Спираючись на наукові здобутки вітчизняних вчених, автор ставить за мету з'ясувати економічні причини низького мотиваційного впливу здійснюваних державою заходів соціально-демографічної політики України у сфері підтримки сімей з дітьми на показники народжуваності в Україні та визначити перспективні напрями забезпечення базових можливостей для реалізації дітородного потенціалу нації.

Виклад основного матеріалу. В зв'язку з кризовим станом економіки України 27 березня 2014 року було прийнято Закон України «Про запобігання фінансової катастрофи та створення передумов для економічного зростання в Україні». Цей закон змінює загальний підхід до виплати державної допомоги сім’ям з дітьми. Так, з 1 липня 2014 року відмінено виплату державної допомоги по догляду за дитиною 
до досягнення нею трьох років, та встановлено однакову суму виплат державної допомоги при народженні дитини незалежно від черговості народження. В результаті цього збільшилася загальна сума допомоги у зв’язку з народженням першої дитини ( з 30960 грн до 41280 грн), та істотно скоротилася сума допомоги у зв’язку з народженням другої та кожної наступної дитини (з 61920 грн та 123840 грн, відповідно, до 41280 грн). Державну допомогу у зв’язку з народженням дитини виплачують у два етапи: I - одноразова виплата у зв'язку з народженням дитини (в обсязі 10 прожиткових мінімумів для дитини у віці до 6 років); II - щомісячні виплати допомоги при народженні дитини (табл. 1).

Слід зазначити, що сума виплат державної допомоги по догляду за дитиною до досягнення нею трьох років, як правило, була незначною. Вона навіть не забезпечувала підвищення рівня доходів сім’ї до прожиткового мінімуму, оскільки сума такої виплати визначалася як різниця між прожитковим мінімумом, встановленим для працездатних осіб, та середньомісячним сукупним доходом сім'ї у розрахунку на одну особу. Фактично компенсувалася різниця між даними показниками для однієї особи, а решта членів сім’ї компенсації не отримували. Таким чином, сукупний дохід сім’ї в розрахунку на одну особу все одно був нижчим за прожитковий мінімум (табл. 1). У випадку, якщо сукупний дохід сім’ї у розрахунку на одну людину перевищував обсяг прожиткового мінімуму, розмір державної допомоги по догляду за дитиною встановлювався у мінімальному розмірі - 130 грн. Тому для більшості жінок, які народили першу дитину, нова програма нарахування виплат державної допомоги є більш вигідною, оскільки покращуються умови життя сім'ї протягом третього року відпустки по догляду за дитиною (табл. 1).

Проте відміна виплат державної допомоги по догляду за дитиною погіршує рівень життя тих сімей, середньодушовий дохід у яких після народження першої дитини є нижчим за прожитковий мінімум, оскільки сума виплат державної соціальної допомоги малозабезпеченим сім'ям з однією дитиною через специфічні особливості розрахунку, як правило, є меншою за суму виплат, яку могла отримати жінка у якості державної допомоги по догляду за дитиною ${ }^{1}$.

Підсумовуючи вищесказане, варто зауважити, що впроваджені зміни можуть мати неоднозначний вплив на дітородні орієнтації населення в майбутньому. Серед позитивних сторін запропонованої програми виплат слід відзначити можливість об’єднання в одну програму кількох дублюючих одна одну програм допомоги сім'ям 3 дітьми, які у своїй сукупності все одно не вирішували повною мірою завдання боротьби з бідністю. При цьому запропоновані зміни парадоксально суперечать принципам соціальної справедливості по відношенню до сім’ї, оскільки зумовлюють подальше зниження рівня життя сімей з народженням другої та кожної наступної дитини, що може негативно позначитися на дітородних планах населення [1]. Відповідно, 3 метою уникнення негативних наслідків у вигляді відмови від народження більш як однієї дитини з економічних причин, паралельно з обмеженням обсягів державної допомоги у зв'язку з народженням другої та кожної наступної дитини, варто було б впроваджувати ефективні програми підтримки дітей у віці від 3 до 18 років. Лише в такому випадку народження додаткової дитини не суперечитиме правам та інтересам уже народжених дітей.

\footnotetext{
${ }^{1}$ При нарахуванні граничної суми виплат державної соціальної допомоги малозабезпеченим сім’ям, рівень забезпечення прожиткового мінімуму для осіб працездатного віку - 21\% прожиткового мінімуму.
} 
Таблиия 1. Порівняння доходів простої повної сім'ї у період перебування жінки у відпустці по догляду за дитиною до досягнення нею трьох років (до та після зміни умов виплати допомоги при народженні дитини)

\begin{tabular}{|c|c|c|c|c|c|}
\hline \multirow{2}{*}{\multicolumn{2}{|c|}{ Параметр }} & \multicolumn{3}{|c|}{ Програма попередніх років } & \multirow[b]{2}{*}{ Нова програма } \\
\hline & & $\begin{array}{l}\text { При наро- } \\
\text { дженні пер- } \\
\text { шої дитини }\end{array}$ & $\begin{array}{l}\text { При наро- } \\
\text { дженні дру- } \\
\text { гої дитини }\end{array}$ & $\begin{array}{c}\text { При на- } \\
\text { родженні } \\
\text { третьої } \\
\text { дитини }\end{array}$ & \\
\hline \multicolumn{2}{|c|}{ Період народження дитини } & \multicolumn{3}{|c|}{31 грудня 2013 р. } & 31 липня 2014 р. \\
\hline \multicolumn{2}{|c|}{ Заробітна плата батька дитини } & \multicolumn{4}{|c|}{3500 грн $^{2}$} \\
\hline \multicolumn{2}{|c|}{$\begin{array}{l}\text { Одноразова виплата держав- } \\
\text { ної допомоги при народженні } \\
\text { дитини }\end{array}$} & \multicolumn{4}{|c|}{10320 грн } \\
\hline \multirow{4}{*}{ 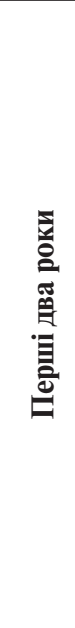 } & $\begin{array}{l}\text { Щомісячні виплати } \\
\text { допомоги по догляду за } \\
\text { дитиною до досягнен- } \\
\text { ня нею трьох років }\end{array}$ & 130,00 грн & 130,00 грн & 203,00 грн & Не виплачується \\
\hline & $\begin{array}{l}\text { Щомісячні виплати } \\
\text { державної допомо- } \\
\text { ги при народженні } \\
\text { дитини }\end{array}$ & $\begin{array}{c}860,00 \text { грн } \\
\text { (протягом } 2 \\
\text { років) }\end{array}$ & $\begin{array}{l}1075,00 \text { грн } \\
\text { (протягом } 4 \\
\text { років) }\end{array}$ & $\begin{array}{c}1576,67 \text { грн } \\
\text { (протягом } 6 \\
\text { років) }\end{array}$ & $\begin{array}{c}\text { 860,00 грн (про- } \\
\text { тягом } 3 \text { років) }\end{array}$ \\
\hline & Сукупний дохід сім'ї & 4490,00 грн & 4705,00 грн & 5279,67 грн & 4360,00 грн \\
\hline & $\begin{array}{l}\text { В розрахунку на одну } \\
\text { особу* }\end{array}$ & 1496,67 грн & 1176,25 грн & 1055,93 грн & $\begin{array}{c}\text { Одна дитина - } \\
1453,33 \text { грн } \\
\text { Дві дитини - } \\
1090,00 \text { грн } \\
\text { Три дитини - } \\
872,00 \text { грн }\end{array}$ \\
\hline \multirow{4}{*}{ 美 } & $\begin{array}{l}\text { Допомога по догляду } \\
\text { за дитиною до досяг- } \\
\text { нення нею трьох років }\end{array}$ & 130,00 грн & 130,00 грн & 203,00 грн & Не виплачується \\
\hline & $\begin{array}{l}\text { Щомісячні виплати } \\
\text { державної допомо- } \\
\text { ги при народженні } \\
\text { дитини }\end{array}$ & $\begin{array}{c}\text { Не виплачу- } \\
\text { ється }\end{array}$ & 1075,00 грн & 1576,67 грн & 860,00 грн \\
\hline & Сукупний дохід сім’ї & 3630,00 грн & 4705,00 грн & 5279,67 грн & 4360,00 грн \\
\hline & $\begin{array}{l}\text { В розрахунку на одну } \\
\text { особу* }\end{array}$ & 1210,00 грн & 1176,25 грн & 1055,93 грн & $\begin{array}{c}\text { Одна дитина - } \\
1453,33 \text { грн } \\
\text { Дві дитини - } \\
1090,00 \text { грн } \\
\text { Три дитини - } \\
872,00 \text { грн }\end{array}$ \\
\hline
\end{tabular}

Джерело: Закон України «Про державну допомогу сім'ям з дітьми». Розраховано автором на основі даних про державні гарантії матеріальної підтримки сімей з дітьми. (2013 p.).

${ }^{2}$ Відповідно до показників середньої заробітної плати в Україні, за даними Державної служби статистики 
Варто наголосити, що запровадження виплат державної допомоги при народженні дитини є значним досягненням у питанні подолання демографічної кризи. Так, одноразова виплата при народженні дитини дає змогу батькам компенсувати витрати на високовартісні покупки дитячих товарів, необхідних у перші роки життя малюка, а щомісячні виплати у подальшому дозволяють придбати необхідний для дитини одяг та продукти харчування. Проте такий фактор мотивації до дітонародження справляє скоріше запобіжний (обмежує подальше скорочення показників народжуваності), аніж стимулюючий вплив. Це означає, що за відсутності подібних виплат від дітонароджень відмовилася б частина тих людей, які бажають та планують народити дитину в найближчі роки, через неспроможність забезпечити ії потреби навіть у перший рік після народження.

Через три роки після народження дитини такі виплати припиняються взагалі. Отже, на даному етапі проблема матеріального забезпечення дитини має вирішуватися лише іiї батьками. При цьому витрати на забезпечення кожної наступної дитини зменшують рівень сукупного середньодушового доходу сім'ї і призводять до зниження рівня життя. Саме тому витрати, з якими доведеться зіткнутися батькам у разі народження наступної дитини, нерідко вони сприймають як загрозу особистому добробуту. Це не означає, що українці взагалі не бажають утримувати своїх дітей, прагнучи перекласти усю відповідальність за їх матеріальне забезпечення на державу. Але значна кількість громадян ладні відмовитися від народження другої чи наступної дитини задля збереження певного досягнутого рівня життя для себе та своїх уже народжених дітей. Такий підхід до планування дітонароджень загалом відповідає пункту 7.3 Програми дій Міжнародної конференції з народонаселення та розвитку, згідно з яким, «подружні пари та окремі особи мають право приймати відповідальне рішення стосовно кількості своїх дітей...», враховуючи при цьому «...потреби своїх уже народжених і майбутніх дітей та свою відповідальність перед суспільством» [2, с. 39].

Слід окремо наголосити, що при виході у відпустку по догляду за дитиною жінка, окрім прямих витрат на виховання дитини, стикається з так званими альтернативними витратами, пов'язаними з їі вимушеною відсутністю на робочому місці ${ }^{3}$. Розглянемо альтернативні витрати жінки від виходу у відпустку по догляду за дитиною до досягнення нею трьох років у випадку, якщо дитина народилася після 1 липня 2014 року, а заробітна плата іï чоловіка становить 3500 грн. За результатами проведених автором розрахунків, протягом усього періоду відпустки по догляду за дитиною до досягнення нею трьох років, щомісячний сукупний дохід сім’ї в розрахунку на одну особу складатиме 1453,33 грн при народженні першої дитини, та 1090,00 грн - при народженні другої дитини (табл. 1).

За даними Державної служби статистики України, середня заробітна плата по Україні за січень-грудень 2013 року становила 3265 грн, а мінімальний рівень середньої заробітної плати, зафіксований у Тернопільській області, - 2359,00 грн [3]. Тож, припустимо, що заробітна плата жінки до народження дитини була 2000,00 грн. Відповідно, сукупний щомісячний дохід сім’ї складав 5500,00 грн. На період перебування жінки у відпустці по догляду за дитиною їі щомісячний дохід скоротиться до 860 грн. (відповідно до умов виплати допомоги у зв`язку з народженням дитини). А це, в свою чергу, призведе до скорочення сукупного доходу сім’ї до 4360 грн щомісячно.

\footnotetext{
${ }^{3}$ Альтернативні витрати жінки від виходу у відпустку по догляду за дитиною до досягнення нею трьох років - це загальна сума доходу, недоотриманого жінкою за час перебування у відпустці по догляду за дитиною.
} 
Відповідно, альтернативні витрати сім’ї від виходу матері у відпустку по догляду за дитиною до досягнення нею трьох років становитимуть 1140,00 грн щомісячно, що у сумі за три роки складе 41040,00 грн. При цьому, щомісячний сукупний середньодушовий дохід сім’ї без дітей після народження першої дитини знизиться з 2750,00 грн. до 1453,33 грн. на одну особу, а щомісячний сукупний середньодушовий дохід сім'ї з однією дитиною після народження другої дитини скоротиться з 1833,33 грн до 1090,00 грн на одну особу.

Так, зокрема, за даними Комітету з питань будівництва, містобудування і житлово-комунального господарства та регіональної політики, лише $56 \%$ українських сімей живуть у власних квартирах і не потребують поліпшення житлових умов. При цьому рівень забезпеченості власним житлом молодих сімей не перевищує 33\% [4].

За даними Державної служби статистки, у грудні 2013 року зарплату нижче середнього рівня (3619 грн. - показник середньої заробітної плати в Україні у грудні 2013 р.) отримало понад 66,5\% найманих працівників [3]. При цьому 45,9\% найманих працівників отримало заробітну плату недостатню для покриття мінімально необхідних витрат на одного дорослого та дитину (прожитковий мінімум для дорослого та дитини у віці від 6 до 18 років - 2504 грн). Фактично це означає, що навіть для повних сімей з обома працюючими батьками, при народженні більш як однієї дитини, зростають ризики бідності та малозабезпеченості [5, с. 83], [5, с. 38]. Це підтверджується результатами обстеження умов життя домогосподарств, яке проводить Державна служба статистики України. Зокрема, «рівень середньодушових доходів у домогосподарствах без дітей приблизно на $40 \%$ перевищує показник по домогосподарствах 3 дітьми» [6, с. 7]. При цьому в «найкращому становищі перебувають сім’ї з однією дитиною», а зростання кількості дітей «суттєво скорочує розмір середньодушових доходів»[6, с.7].

Важливою проблемою є і невідповідність між задекларованим рівнем прожиткового мінімуму та фактичною вартістю життя в Україні. Так, при розрахунку величини прожиткового мінімуму в Україні не враховано витрати на оренду чи придбання житла, навчання, виховання та розвиток дітей, охорону здоров'я тощо [7, с. 109]. Окрім того, в загальній структурі споживчого кошика, що використовується при розрахунку прожиткового мінімуму, близько 60\% витрат складають витрати на продукти харчування [7, с. 109]. Тоді як у провідних країнах заходу цей показник не перевищує 30-50\%.

Водночас у США та розвинутих країнах Євросоюзу є значна кількість програм, спрямованих на підтримку малозабезпечених та соціально вразливих верств населення, особливо сімей з дітьми, серед яких: програма допомоги у додатковому харчуванні (SNAP), програма самодопомоги у придбанні власного житла (SHOP), допомога на оренду житла, субсидії на догляд за дітьми (у період роботи та/або навчання батьків). При цьому за методикою оцінки малозабезпеченості, що використовується у США, до категорії малозабезпечених в Україні мали б потрапити сім’ї, рівень доходів яких у розрахунку на одну особу не перевищує 2436 грн ${ }^{4}$. Тобто, за мірками розвинутих країн світу, значна частка населення України є бідною.

Як бачимо, забезпечення елементарних потреб людини, гарантованих Конституцією України, вимагає або істотного підвищення рівня оплати праці (підвищення мінімальної заробітної плати до рівня покриття прожиткового мінімуму для одно-

\footnotetext{
${ }^{4}$ Право на участь у програмі допомоги у додатковому харчуванні (SNAP) мають сім’і, що витрачають на придбання мінімально-необхідного набору продуктів харчування більш як $30 \%$ чистого доходу (валовий сукупний дохід за виключенням окремих витрат, таких як плата за житло, догляд за дітьми тощо).
} 
го працездатного члена сім’ї та однієї дитини), зростання прожиткового мінімуму (з включенням додаткових витрат: на оренду чи придбання житла, навчання та розвиток дитини, охорону здоров'я), або розширення соціальних гарантій та державної підтримки (створення умов для самозабезпечення населення власним житлом: субсидіювання будівництва та оренди житла, зміни підходів до віднесення сім’ї до категорії малозабезпечених). При цьому слід зазначити, що значне скорочення соціальних гарантій сім’ям з дітьми, навіть за істотного підвищення доходів громадян, спричиняє зменшення мотивації дітонароджень і практично зводить до мінімуму можливості державного впливу на дітородну поведінку населення. Адже в даному випадку інвестиції, необхідні для народження та виховання дитини, потенційні батьки розглядають як альтернативні витрати, що зумовлюють зниження їх особистого добробуту.

Забезпечення сталого людського розвитку в Україні вимагає додаткових інвестицій у розвиток та підвищення рівня життя дітей з боку держави шляхом впровадження компенсаційних виплат. Необхідність впровадження таких заходів, як засіб активної демографічної політики, базується на припущенні, що витрати на розвиток дитини повинні справедливо розподілятися між державою та батьками. Так, на сьогоднішній день в Україні уся матеріальна відповідальність за виховання та розвиток дитини після досягнення нею трирічного віку покладена на батьків. Внесок держави полягає в організації безоплатної початкової та середньої освіти й охорони здоров'я. Проте останніми роками намітилися тенденції, що показують неспроможність держави якісно організувати виконання навіть цих функцій. Зі зростанням особистого доходу, люди більше прагнуть підвищити власні інвестиції у навчання та розвиток уже народжених дітей, ніж народити ще одну дитину. Це зумовлено незадовільною якістю та недостатнім обсягом тих послуг щодо навчання, розвитку, охорони здоров'я дітей, які надає держава. При цьому у кількісному відтворенні людських ресурсів та формуванні якісного людського капіталу держава зацікавлена не менше, ніж батьки. Саме тому доцільно було б частково компенсувати витрати на виховання та розвиток майбутніх поколінь, зменшуючи таким чином негативний мотиваційний вплив на репродуктивну активність населення, з одного боку, та забезпечуючи рівні умови для розвитку дітей, незалежно від доходів їхніх батьків, з другого. Такий розподіл витрат базується на стратегічній доцільності інвестицій грошових коштів у розвиток людського капіталу для забезпечення сталого людського, соціального та економічного розвитку.

Позитивною рисою системи компенсаційних виплат є їх адресний характер: батькам, в межах наперед встановленого ліміту, компенсуються затрати на певні види товарів та послуг для дітей. Це, з одного боку - дає батькам можливість обирати ті товари і послуги, які, на їхню думку, є кориснішими для дітей, а з другого - забезпечує контроль з боку держави за тим, щоб грошові кошти, призначені для дитини, використовувалися виключно для задоволення iї потреб. Прикладом таких виплат може бути компенсація витрат на навчання дитини у спеціалізованих школах та гуртках (музичних, художніх, спортивних тощо), які переважно є платними, або компенсація витрат на придбання необхідних для розвитку дитини матеріалів (музичних інструментів, форми, підручників тощо).

Спираючись на практичний досвід провідних країн світу, доречніше вважати базою для розрахунку граничної величини компенсаційних виплат сукупний дохід сім'ї, що безпосередньо витрачається на споживання в розрахунку на одного члена сім'ї. Під величиною сукупного доходу, що безпосередньо витрачається на споживання, розуміють 
суму доходів, отриманих протягом місяця усіма членами сім’ї, за вирахуванням 70\% від суми грошових коштів, що їх витрачає сім'я на оплату оренди житлового приміщення, виплати по іпотечному кредитуванню, сплату за житло, придбане на інших умовах, будь-які інші виплати за користування житловим приміщенням. Варто зауважити, що в даному випадку, йдеться не про компенсацію вартості оренди чи придбання житла, а про підвищення суми часткової компенсації грошових коштів, необхідних для покриття прожиткового мінімуму дитини у разі, якщо батьки дитини змушені орендувати чи купувати житло. Необхідність включення затрат на оренду чи придбання житла до розрахунку компенсаційних виплат випливає зі змісту статей 47 та 48 Конституції України, п.1, 3 статті 27 Конвенції про права дитини. Адже цілком логічно, що грошові кошти, які батьки сплачують за користування житлом, вони не можуть витрачати на потреби виховання, розвитку та підтримки життєдіяльності своєї дитини.

При цьому доречно було б ввести систему диференційованих компенсаційних виплат, гранична величина яких зменшується пропорційно зростанню середньодушового доходу сім’ї від 1 до 0,25 прожиткового мінімуму на дитину відповідного віку. Так, сім’і, у яких розмір сукупного середньодушового доходу, що безпосередньо витрачається на споживання, до народження дитини не перевищує 1 прожитковий мінімум, не спроможні забезпечити достойний рівень життя, гарантований статтею 48 Конституції України, навіть для самих себе. Тому сума компенсаційних виплат на виховання і розвиток новонародженої дитини у такій сім’ї має становити 100\% прожиткового мінімуму для дитини відповідного віку. Подальше зростання розміру сукупного середньодушового доходу сім'ї, що безпосередньо витрачається на споживання до народження дитини, на кожні $2 \%$ має супроводжуватися скороченням суми компенсаційних виплат на $1 \%$. Це забезпечить часткову економію бюджетних коштів. При цьому більш повільний темп скорочення ліміту суми компенсаційних виплат, порівняно з темпом зростання середньодушового доходу сім'ї, забезпечить збереження мотивації до продуктивної праці, оскільки зберігатиметься диференціація реальних доходів громадян залежно від їх трудових досягнень. Граничною межею для призначення підвищеного розміру компенсаційних виплат має бути такий рівень сукупного середньодушового доходу сім'і, що забезпечував би повноцінне задоволення основних потреб людини. За приблизними розрахунками профспілок, реальний прожитковий мінімум, що забезпечив би повноцінне відтворення та розвиток людського капіталу, має становити не менше 3000 гривень [8]. Таким чином, сім'ям, у яких сукупний середньодушовий дохід, що безпосередньо витрачається на споживання до народження дитини, перевищує 2,5 прожиткових мінімуми, доцільно надавати мінімальний розмір компенсації затрат на виховання та розвиток дитини в обсязі 25\% прожиткового мінімуму для дитини відповідного віку.

Мотиваційний ефект запропонованих заходів полягає у значному скороченні економічних втрат, пов'язаних з народженням дитини. Так, у випадку, якщо середньомісячний сукупний дохід сім'ї складає 5500 грн, то розмір середньодушового доходу у такій сім'ї без дітей - 2750 грн. Після народження першої дитини та досягнення нею трирічного віку середньодушовий дохід сім’ї скоротиться з 2750 грн до 1833 грн в розрахунку на одну особу (на 33\% у порівнянні з аналогічною сім'єю без дітей). Народження другої і кожної наступної дитини ще більше скорочуватимуть частку доходу сім'ї, що витрачається на споживання однією особою (див. рис.1). При цьому право на отримання державної соціальної допомоги малозабезпеченим сім'ям (у розмірі 1727,06 грн) у сім'ї з сукупним середньомісячним доходом у розмірі 5500 грн з'являється лише з народженням п'ятої дитини. 
Проблема суттєво ускладнюється недостатньою доступністю житла для молодих сімей з дітьми. Коли сім'я з сукупним середньомісячним доходом 5500 грн орендує житлове приміщення, сплачуючи за нього 2000 грн/міс, безпосередньо на споживання залишається 3500 грн/міс. У випадку народження більш як однієї дитини така сім'я не може забезпечити задоволення навіть своїх базових потреб (розмір середньодушового доходу сім’ї, що безпосередньо витрачається на споживання, $є$ значно меншим за величину прожиткового мінімуму).

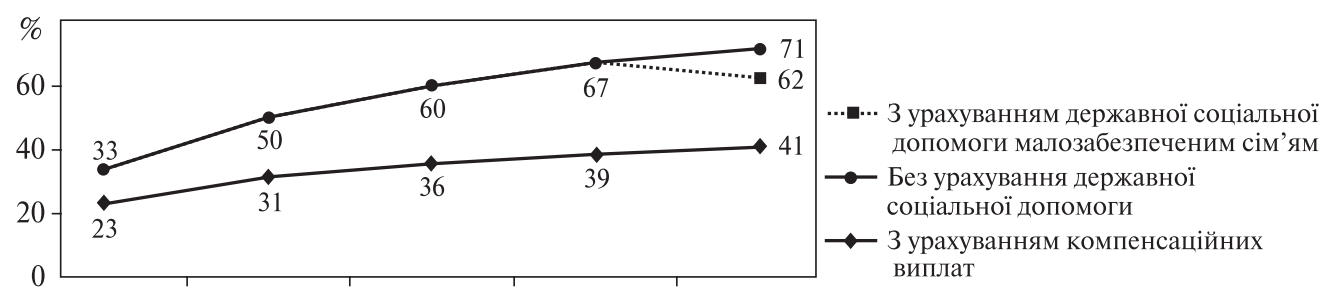

Рис. 1. Відносні втрати середньодушового доходу сім'ї у зв'язку з народженням дитини порівняно з домогосподарством без дітей

Джерело: Закон України «Про державну соціальну допомогу малозабезпеченим сім'ям». Розраховано автором на підставі даних про обсяги державної соціальної допомоги.

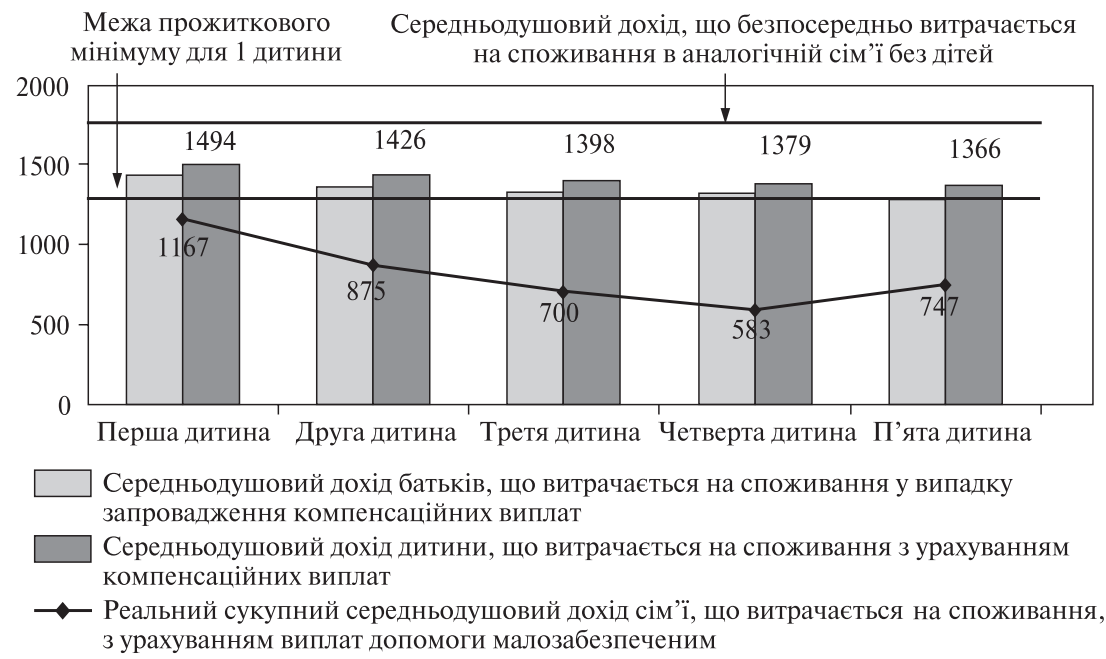

Рис. 2. Підвищення рівня життя сімей з дітьми за рахунок компенсації витрат на виховання та розвиток дітей, якщо сукупний дохід сім’ї складає 5500 грн, а витрати на оренду житла 2000 грн $^{6}$

Джерело: Закон України «Про державну соціальну допомогу малозабезпеченим сім'ям». Розраховано автором на підставі даних про обсяги державної соціальної допомоги.

5 За умови, що сукупний дохід сім’ї складає 5500 грн/місяць і 2000 грн/місяць витрачається на оренду житла.

${ }^{6}$ Середня вартість довгострокової оренди однокімнатної квартири по Україні вцілому, за даними аналітиків сайту приватних оголошень Slando (вересень, 2013 р.). 
Тому народження кожної наступної дитини в такій сім’ї порушує права й інтереси вже народжених дітей. Зрозуміло, що такі тенденції не сприяють підвищенню фертильності серед населення України. Натомість, як видно з рис. 2, запропонована методика виплати компенсації витрат на виховання та розвиток дитини зменшує негативні фінансові наслідки багатодітності.

Висновки. Як показали результати дослідження, проблема низької фертильності українського населення обумовлена низкою соціально-економічних причин. Отже, iі вирішення вимагає глибинних перетворень у системі перерозподілу доходів, підвищення рівня життя населення, створення додаткових гарантій соціальної підтримки сімей з дітьми. Забезпечення простого відтворення населення вимагає підвищення рівня мінімальної заробітної плати принаймні вдвічі, що дало б можливість будьякій працюючій людині утримувати на одну заробітну плату себе і дитину. Окрім того, важливого значення набуває забезпечення житлом молодих сімей, підвищення показників зайнятості тощо. Вирішення усіх цих завдань у короткостроковій перспективі видається малоймовірним.

Одним з напрямів подолання демографічної кризи можна вважати цільові інвестиції на виховання, розвиток та покращення життя дітей. Запровадження компенсаційних виплат на виховання та розвиток дитини забезпечило б базові можливості для реалізації дітородного потенціалу нації, давши змогу кожній сім’ї народити та виховати бажану кількість дітей ${ }^{7}$. Позитивними сторонами запропонованої програми є комплексний вплив на ряд соціально-економічних проблем, з якими стикаються сім’ї з дітьми, збереження мотивації батьків до трудової діяльності й саморозвитку та відсутність мотивації до дітонародження з метою отримання економічної вигоди. Основним недоліком є необхідність залучення значних матеріальних ресурсів на фінансування програми, що виявляється неможливим без грунтовного перегляду системи розподілу та перерозподілу ресурсів та оптимізації виробництва з метою підвищення продуктивності праці.

\section{ЛІТЕРАТУРА}

1. Висновок Головного науково-експертного управління Апарату Верховної Ради України на проект Закону України «Про запобігання фінансової катастрофи та створення передумов для економічного зростання в Україні» від 27.03.2014 / [Пархоменко Н., Чечетова Н., Олещенко О. та ін.]. - [Електронний ресурс] - Режим доступу: URL: http://w1.c1.rada.gov.ua/pls/zweb2/webproc4_1?pf3511=50437 - Офіційний веб-портал Верховної Ради України.

2. Доклад Международной конференции по народонаселению и развитию (Каир, 5-13 сент. 1994 г.) [Текст] - Нью-Йорк: ООН, 1995. - 198 с.

3. Середньомісячна заробітна плата за регіонами за період з початку року у 2013 році (в розрахунку на одного штатного працівника, грн). - [Електронний ресурс]. - Режим доступу: URL: http://www.ukrstat.gov.ua/ - Офіційний сайт Державної служби статистики.

4. Завгородня Ольга. Лише 56\% українських родин мають власне житло / Завгородня Ольга. [Електронний ресурс] - Режим доступу: URL: http://www.unn.com.ua/uk/news/965414-lishe56proc-ukrayinskih-rodin-mayut-vlasne-geitlo - Українські Національні Новини (УНН). - 12 жовтня $2012 \mathrm{p}$.

5. Ничипоренко С.В. Молодіжна сімейна політика в Україні / Ничипоренко С.В. - Умань: Видавець «Сочінський», 2011. - 217 с.

6. Нерівні можливості дітей в Україні: аналіз та рекомендації для політики (на основі моніторингу щодо економічної нерівності домогосподарств та доступу дітей до послуг соціальної сфери) /

7 2,19 дітей на одну сім’ю - за даними опитування, яке провів Інститут демографії і соціальних досліджень ім. М.В. Птухи НАН України. 
[Черенько Л.М., Полякова С.В., Шишків В.С., Заяць В.С. та ін.]. - К.: Ін-т демографії та соціальних дослід. НАН України, Дитячий фонд ООН (ЮНІСЕФ), Укр. центр соціальних реформ, 2011. $-47 \mathrm{c}$.

7. Пищуліна О.М. Зміна методики розрахунку прожиткового мінімуму - крок до реформування соціальної політики / О.М. Пищуліна // Стратегічні пріоритети. - 2009. - № 1(10). C. $106-114$.

8. Ільчук Л.І. Оцінка фінансування соціальних виплат за умови зміни розмірів прожиткового мінімуму та відміни пільг / Л.I. Ільчук. - [Електронний ресурс]. - Режим доступу: URL: http:// cpsr.org.ua/index.php?option $=$ com_content\&view $=$ article\&id=381:-r\&catid=20:2010-06-13-21-06$26 \&$ Itemid=27 - Центр перспективних соціальних досліджень Міністерства соціальної політики України. - 23 квітня 2014 p.

\section{REFERENCES}

1. Vysnovok Holovnoho naukovo-ekspertnoho upravlinnia Aparatu Verkhovnoi Rady Ukrainy na proekt Zakonu Ukrainy «Pro zapobihannia finansovoi katastrofy ta stvorennia peredumov dlia ekonomichnoho zrostannia v Ukraini» vid 27.03.2014 [Opinion Main Scientific Expert Department of the Verkhovna Rada of Ukraine the draft Law of Ukraine «On prevention of financial disaster, and creating conditions for economic growth in Ukraine» from 03.27.2014]. rada.gov.ua. Retrieved from http://w1.c1.rada.gov. ua/pls/zweb2/webproc4_1?pf3511=50437 [in Ukrainian].

2. Doklad Mezhdunarodnoj konferentsyy po narodonaselenyiu y razvytyiu: Kayr, 5-13 sent. 1994 [The report international conference on narodonaselenyyu and Development: Cairo, 5-13 sept. 1994]. (1995) New York: UN [in Ukrainian].

3. Serednomisiachna zarobitna plata za rehionamy za period z pochatku roku u 2013 rotsi (v rozrakhunku na odnoho shtatnoho pratsivnyka, hrn) [Average salary by region since the beginning of the year in 2013 (per one employee, hr.)] www.ukrstat.gov.ua. Retrieved from http://www.ukrstat.gov.ua/ [in Ukrainian].

4. Zavhorodnia Olha. (2012, 12 October). Lyshe 56\% ukrainskykh rodyn maiut vlasne zhytlo / Zavhorodnia Olha. [Only $56 \%$ of Ukrainian families have their own home]. www.unn.com.ua. Retrieved from http://www.unn.com.ua/uk/news/965414-lishe-56proc-ukrayinskih-rodin-mayut-vlasne-geitlo [in Ukrainian].

5. Nychyporenko S.V. (2011). Molodizhna simejna polityka v Ukraini [Youth family policy in Ukraine]. Uman': Vydavets' «Sochins'kyj» [in Ukrainian].

6. Cheren'ko L.M., Poliakova S.V., Shyshkiv V.S., Zaiats' V.S. et al. (2011). Nerivni mozhlyvosti ditej v Ukraini: analiz ta rekomendatsii dlia polityky (na osnovi monitorynhu schodo ekonomichnoi nerivnosti domohospodarstv ta dostupu ditej do posluh sotsial'noi sfery) [Unequal opportunities for children in Ukraine: analysis and policy]. - Kyiv: Institute of Demography and Social Research. National Academy of Sciences of Ukraine, the UN Children's Fund (UNICEF) [in Ukrainian].

7. Pyschulina O.M. (2009). Zmina metodyky rozrakhunku prozhytkovoho minimumu - krok do reformuvannia sotsial'noi polityky [Changing the method of calculation of a living wage - a step to reform social policy]. Stratehichni priorytety - Strategic Priorities, 1(10), 106-114. [in Ukrainian].

8. Il'chuk L.I. (2014, 23 April) Otsinka finansuvannia sotsial'nykh vyplat za umovy zminy rozmiriv prozhytkovoho minimumu ta vidminy pil'h [Evaluation of financing social benefits provided resizing a living wage and the abolition of privileges]. cpsr.org.ua. Retrieved from: http://cpsr.org.ua/index. php?option $=$ com_content $\&$ view $=$ article $\&$ id $=381:-r \&$ catid $=20: 2010-06-13-21-06-26 \&$ Itemid $=27$ [in Ukrainian].

Стаття надійшла до редакції журналу 15.05.2014 